This is an open access article under the terms of the CC-BY 3.0 License.

Peer review method: Double-Blind

Date of acceptance: June 18, 2020

Date of publication: August 14, 2020

Original scientific article

DOI https://doi.org/10.47305/JLIA2020010am

UDC 35.08:342.565.4(497.7)

\title{
SECOND INSTANCE ADMINISTRATIVE COMMISSIONS AND THE ADMINISTRATIVE COURTS EFFICIENCY IN THE REPUBLIC OF NORTH MACEDONIA
}

\author{
Iskra Akimovska Maletic \\ Faculty of Security - Skopje, University "St. Kliment Ohridski" - Bitola, North Macedonia \\ ORCID iD: https://orcid.org/0000-0002-4929-7023 \\ iskra.maletic@fb.uklo.edu.mk

\section{Dragan Gocevski} \\ Faculty of Law "lustinianus Primus", University "Ss Cyril and Methodius" - Skopje, North Macedonia \\ ORCID iD: https://orcid.org/0000-0001-8796-5697 \\ d.gocevski@pf.ukim.edu.mk
}

\begin{abstract}
The paper aims to evaluate the direct and indirect determinants of the system for administrative legal protection efficiency in the Republic of North Macedonia. For this purpose, the paper analyzes the legal and institutional framework of administrative authorities i.e. the second instance administrative commissions that act on the appeal against the decisions of the first instance administrative bodies, as well as the legal and institutional framework of the Administrative and Higher Administrative Court that provide administrative-judicial protection against administrative acts. The paper assesses internal efficiency determinants for three second instance state commissions that provide legal protection in administrative procedure in the country, independently, as well as the two administrative courts: staff (administrative staff, number of elected members of second instance commissions, number of judges), number of newly formed cases, number of resolved cases and number of unresolved cases at the end of a year.
\end{abstract}

Keywords: Administrative Legal Protection; Clearance Rate; Public Sector; Second Instance Administrative Commissions; Administrative Courts; North Macedonia 


\section{INTRODUCTION}

Authorities conducting administrative procedures, decision makers on administrative matters are obligated to secure successful and quality provision of civil rights, legal interests and duties before the state to all parties in i.e. citizens and businesses. Understanding efficiency as a specific reflex of the principle of legality, legal protection against infringement on the former is considered violation of the latter. This means that parties in administrative procedures and administrative dispute are provided right of objection, appeal and law-suit when their rights are violated as a resulted of administrative inefficiency in the same capacity and legal format provided in any other administrative process. Efficiency is considered by many a prime principle of government operation, very much like the principle of effectiveness. Efficiency is a measure of how much each unit of input (every effect, result of any service) costs (expressed in invested time, manpower and other resources), while effectiveness is a measure of quality of such outputs, i.e. how well the desired effect is achieved.

Generally speaking, efficiency may be perceived as a true (real) effect of productiveness achieved by execution of specific tasks, assessed by whether intended goals were met or not, or whether the expected output from an administrative process is the one desired in the moment the process was initiated. In this more generalized context, efficiency may include quality, effectiveness, expediency and speed (economics) of administrative work (Dimitrijevic 2017, 325). This paper presents the results of observed and measured efficiency indicators for the institutions providing legal protection in administrative proceedings in the Republic of North Macedonia', individually per institution as well as aggregated in a panel, observed and measured as a single system for provision of administrative legal protection. The research' goal was to determine direct and indirect predictors of efficiency in the system for administrative legal protection in North Macedonia.

The population or total number of units of observation comprising the system for administrative legal protection in North Macedonia is seven public institutions, five of which are subject of this research. The period of observation for selected institutions was the entirety of their existence since they were established until the end of 2017. Three of these institutions are independent state bodies: State Commission for Decision Making in Second Instance in Administrative Procedures and Labor Disputes, the State Commission for Decision Making in Second Instance Inspection Oversight and State Commission for Appeals in Public Procurements. The other two are courts: Administrative Court Skopje and Higher Administrative Court. This research does not cover the following ministerial commissions: The Commission for Appeals in the Ministry of Labor and Social Policy and the Commission for Appeals in the Ministry of Healthcare.

\footnotetext{
${ }^{1}$ Further in the text: North Macedonia.
} 


\section{THEORETICAL FRAMEWORK}

Nashold and Otter argued in 1996 that government policy must take greater account of economic criteria of efficiency and effectiveness. The use of social resources must be continuously subject to the requirement that they be employed efficiently and effectively, implying both a rise in intra-administrative efficiency and also an economic calculation of alternative uses and modes of application (Nashold and Otter 1996, 62).

Finding a common unit of measurement [however] or as Koprić formulated it a 'common meter' poses a methodological challenge when comparing and determining commonalities in administrative systems of different countries (Koprić 2011, 10). The same challenges stand when attempting to compare and measure different aspects of operation between institutions within the same country. Though differences between administrative systems indisputably exist, still certain common traits of internal organization and thus factors that affect productiveness i.e. predictors of it can be found and subjected to the same working principles.

Let us take the study by Gomes, Guaimaraes and Akutsu from 2016 when they measured the effect that employees have on productiveness of courts in Brazil. Despite evident variation in the internal workings between courts from country to country stemming from institutional idiosyncrasies, traits of the political systems and contemporary political context in the state, even in very similar judicial systems the authors justified studying the effects of staff on the productiveness of courts. Their research answers how (if at all) one can influence judicial productiveness by employing or dismissing staff (Gomes, Guaimaraes and Akutsu 2016, 12). The category 'staff' in their study included the entire labor force involved in judicial proceedings comprising judges and administrative servants. This approach is inclined to the general theory of productiveness assuming that efficient allocation of labor and capital in an organization has positive effects on the organization's productiveness (OECD 2018).

Technical solutions for comparison of different judicial systems are present in the practice of the European Commission' EU Judicial Scoreboard, as well the CEPEJ publication by the Council of Europe. Both utilize the same efficiency indicators: clearance rate, disposition time and backlog (EU Justice Scoreboard 2018, 10-16).All three are accepted as applicable efficiency indicators regardless of specifics and internal organization of judicial system. From this position we established the assumption that as long the nature of productive process is not significantly different between two or more organizations (any organization), their productiveness i.e. efficiency can be measured using the same set of indicators. In this studies sample, state bodies providing appellative protection in administrative procedures and the administrative courts providing legal protection in administrative disputes essentially perform a similar/near identical task which is overseeing the legality of an individual administrative act being contested before it. The act being contested is one made by an administrative authority deciding on civil rights and duties. Thus, we argue their performance may be measuring utilizing a same set of indicators on the 
sample as hole as well by status, hence forming two comparable groups. Statistically significant differences in the productivity of each group (if any exist) may be ascribed to the specifics of internal organization, as well as external factors such as the legal framework conditioning each group of institutions to different regime of operating. State bodies are in essence administrative organizations and as such subjected to general administrative procedure, characterized by prescribed (fixed) deadlines. Administrative courts do not have an explicit deadline in which they must process a case and reach a verdict (with exception to cases related to elections, misdemeanor or other urgent cases), however judges are given a monthly quota expressed in a number of minimum cases each judge must resolve in every month. Other external factors of productivity specific to each institution, which are not quantitatively described in this study but were noted during interviews by staff working in the observed institutions include: working conditions, the quality of intra-institutional communications, do institutions deliver cases between them-selves quickly and without errors in documentation, ICT and other equipment at their disposal etc. (Gocevski 2017, 45, 47, 50, $69,73)$.

The working hypothesis $(H)$ is that institutional efficiency (dependent variables $Y_{1}, Y_{2}$, Y3 per individual institution) achieved through adequate allocation of labor and resources affects systemic efficiency (regression coefficient for each $Y$ in a multivariate linear regression, of $X 1$ and $X 2$ explain a larger variance in the value of $Y$, i.e. is greater than 0.5 , and probability that beta coefficients for $X 1$ and $X 2$ are chance results is low enough, i.e. $p<0.05$ ).

A null Hypothesis would be that institutional efficiency cannot be explained in meaningful and significant way by the independent variables, nor can the systemic efficiency be explained in a meaningful and significant way by $X 1$ and $X 2$ of each institution, per year and placed in a panel regression (expected $R^{2}$ for $X 1$ and $X 2$ is below .05, or the probability that beta coefficients for $X 1$ and $X 2$ are chance results is too high, i.e. $p>0.05$ ).

The adequacy of internal allocation of staff and resources is explained by the amount of work per institution, per number of staff, for each observed year (explanatory variables). Other factors such as the level of ICT utilization, quality of inter-institutional communication channels have an intervening effect acting as moderators of systemic efficiency (Intervening variables) and thus explain some of the value (or variance in values) of performance indicators $(\mathrm{Y} 1, \mathrm{Y} 2, \mathrm{Y} 3)^{2}{ }^{2}$

Research questions set are:

Rq1: Do the independent variables in this research affect institutional efficiency equally and in a consistent manner regardless of the type of institution?

Rq2: Does the presence of prescribed deadlines or quotas per employee affect institutional efficiency differently?

\footnotetext{
${ }^{2}$ More on institutional productivity, with similar variables: Gomes at all, 2016, Lindsay and McQuaid 2008; Quist 2016.
} 


\section{Independent $(X)$ and explanatory (e) variables:}

X1, number of decision makers: judges in courts, members of commissions

$\mathrm{X} 2$, number of administrative servants

e1, number of administrative servants per decision maker

e2, number of newly formed cases

e3, backlog (stock of unresolved cases) at the end of the previous year

e4, number of cases solved in the current year

e5, unresolved cases at the end of the current year

e6, total number of cases in the current year

e7, workload per decision maker

e8, workload per administrative servant

\section{Moderator (Int) and dependent (Y) variables:}

Y1, Clearance rate (e4/e2) [selected variable in testing]

Y2, Disposition time (e5/e4*365) [not tested]

Y3, Backlog (e5/population of RNM *100) [not tested]

Int - qualitatively obtained information, not present in the quantitative analysis: working conditions, quality of inter-institutional communication, regularity of delivered documents from one institution to another) etc.

$X 1, X 2 \rightarrow e \rightarrow$ Int $\rightarrow$ Y

Hypothesis diagram 


\section{OVERVIEW OF OBSERVED POPULATION}

\section{State Commission for Appeals in Public Procurements}

State Commission for Appeals in Public Procurements was established 2007 and began operating in 2008 as an independent state body. The same status applies to the two other commissions observed in this study. The Commission is composed of a president and four members elected by the national assembly to a five-year mandate. It is competent to decide on appeals in public procurement procedures, against administrative decisions to awarded public procurement contracts, concessions, and public private partnership. Public procurement procedures are considered a special type of administrative procedures. Legal protection is provided in all phases of the process, from publication of the call for bids to the award of contract. ${ }^{3}$ The commission is obligated with a prescribed deadline to decide within 15 days of forming a case, by decision in the form of an 'individual administrative act'. ${ }^{4}$ Said decision is considered final but not conclusive, meaning that a dissatisfied party no longer has any legal remedies in administrative procedure but is however permitted to initiate an administrative dispute, before an administrative court of first instance. The courts' verdict can then be appealed before the Higher Administrative Court. Administrative disputes are considered judicial proceedings, and when deciding on public procurement cases proceedings are considered urgent.

\section{Table 1: State Commission for Appeals in Public Procurements}

2008200920102011201220132014201520162017

Members of the Commission

\section{Administrative Servants}

Cases from Previous year

Newly formed cases

Total workload (total cases being processed)

\section{Solved}

Unsolved

Disposition time

Clearance rate

Back log. Rate of unsolved cases per 100 out of the total population

$\begin{array}{rrrrrrrrrr}5 & 5 & 5 & 5 & 5 & 5 & 5 & 5 & 5 & 5 \\ 5 & 5 & 6 & 8 & 9 & 9 & 10 & 15 & 13 & 12 \\ 0 & 48 & 48 & 48 & 24 & 24 & 28 & 16 & 16 & 17 \\ 530 & 1044 & 820 & 642 & 561 & 509 & 563 & 610 & 607 & 544 \\ 530 & 1092 & 868 & 690 & 585 & 533 & 591 & 626 & 623 & 561 \\ 482 & 996 & 820 & 666 & 561 & 505 & 575 & 610 & 606 & 548 \\ 48 & 48 & 48 & 24 & 24 & 28 & 16 & 16 & 17 & 13 \\ 36.3 & 17.6 & 21.4 & 13.2 & 15.6 & 20.2 & 10.2 & 9.6 & 10.2 & 8.7 \\ 0.9 & 1.0 & 1.00 & 1.04 & 1.00 & 0.99 & 1.02 & 1.00 & 1.00 & 1.01 \\ 0.0 & 0.0 & 0.00 & 0.00 & 0.00 & 0.00 & 0.00 & 0.00 & 0.00 & 0.00\end{array}$

\footnotetext{
${ }^{3}$ Before this Commission was established, dissatisfied parties in public procurement procedures known as economic operators, could contest the decision to elect a most favorable by appealing to a second instance commission formed within the Government of the state, see: Gocevski 2017, 25.

${ }^{4}$ Art. 224 para. 6 Law on Public Procurements (Official Gazette of RM no. 136/2007, 130/2008, 97/2010, 53/2011, 185/2011).
} 
The State Commission for Decision Making in Second Instance Administrative Procedure and Labor Disputes (Akimovska Maletic and Dimitrijevic 2015, 493-494) (s $^{5}$ an independent state body. Its composition includes a president and ten members elected and dissolved by the national assembly, upon nomination by the Committee for Elections and Appointments to a fiveyear mandate. The competence of this commission extends to deciding on appeals against first instance administrative decisions made by ministries, other state bodies of administration, organizations with public competencies and other bodies of state; and deciding on appeals against decisions made in labor disputes between public institutions as employers and their employees with the status of public sector employees [except employees with the status of administrative servants, who realize this right before another body of state, the Agency for Administration]; deciding on appeals against reward abolishment acts by the Ministry of Interior; and deciding on appeals against first instance decisions by the Securities Commission.

Regarding labor disputes, the competence of this commission extends to appellative protection of employment rights to public service providers, persons with special authorization and logistical staff in large variety of public institutions: Ministry of Internal Affairs (uniformed and civilian personnel), the Army, prison police, public healthcare institutions etc. The only administrative servants that protect their employment rights before this body are those employed in the Agency for Administration, which is in fact competent to provide appellative protection to all other administrative servants.

The full administrative competencies of this commission are derived from over 150 laws governing special administrative procedures: pension and invalid insurance, education, culture, transport and connections, legalizing infrastructure and buildings [unlawfully constructed], privatizing construction land etc. ${ }^{6}$ Before the commission was established, this competence was vested in various appellative commissions within the Government of the state (Gocevski 2017, 30). This commission is obligated with a prescribed general deadline, to decide within two months of receiving an appeal, unless otherwise mandated by a special law to decide within a shorter deadline. When deciding upon an appeal against brought against a decision once nullified in a previous proceeding, the commission is obligated to decide in full competence i.e. merit and resolve the case in full. The administrative decisions [considered second instance] by this commission are considered final but not conclusive and may be contested in administrative dispute before an Administrative court of first instance. Decisions the commission makes in labor disputes may be contested before a civil labor court.

\footnotetext{
${ }^{5}$ State Commission was established with the Law on Establishment of the State Commission for Decision Making in Second Instance Administrative Procedure and Labor Disputes(Official Gazette of RM no. 51/11, 148/13, 41/14, 130/14, 53/2016 and 11/2018).

${ }^{6}$ From 2014 to 2015 it was competent to decide in second instance procedures of inspection oversight.
} 
Table 2: State Commission for Decision Making in Second Instance Administrative Procedures and Employment Disputes

\begin{tabular}{l|rrrrrr} 
& 2012 & 2013 & 2014 & 2015 & 2016 & 2017 \\
\hline Members of the Commission & 7 & 7 & 11 & 11 & 11 & 11 \\
\hline Administrative Servants & 22 & 25 & 49 & 53 & 48 & 65 \\
\hline Cases from Previous year & 3539 & 3727 & 1763 & 1425 & 791 \\
\hline Newly formed cases & 11472 & 7147 & 5427 & 4667 & 4883 & 3921 \\
\hline Total workload (total cases being processed) & 11472 & 7264 & 8365 & 6064 & 5517 & 4756 \\
\hline Solved & 8619 & 3725 & 4104 & 41714092 & 4408 \\
Unsolved & 2853 & 3422 & 1323 & 496 & 791 & 754 \\
\hline Disposition time & 120.8335 .3 & 117.7 & 43.4 & 70.6 & 62.4 \\
Clearance rate & 0.75 & 0.52 & 0.76 & 0.89 & 0.84 & 1.12 \\
\hline Back log. Rate of unsolved cases per 100 out of the total population & 0.14 & 0.17 & 0.07 & 0.02 & 0.04 & 0.04
\end{tabular}

State Commission for Decision Making in Second Instance Inspection Oversight and Misdemeanors

The State Commission for Decision Making in Second Instance Inspection Oversight and Misdemeanors was established in $2015,{ }^{7}$ as an independent state body. Its composition includes a president and six members elected and dissolved by the national assembly for a mandate of five years. These commissions' competencies extend to deciding on appeals against administrative decisions made in first instance inspection oversight; and on appeals against administrative decisions on misdemeanors made by [first instance] misdemeanor authorities. It has a prescribed deadline to decide within two months of receiving an appeal. Just as the previous commission (see 3.2) when deciding on an appeal brought against a decision, once nullified in a previous proceeding it must resolve the case in full merit.

The commissions' decisions are considered [second instance administrative] final but not conclusive and may be contested in administrative dispute before an Administrative court of first instance, followed by the right of appeal before the Higher Administrative Court. The plaintiff's lawsuit does not postpone enforcement of the commissions' decision. ${ }^{8}$

\footnotetext{
${ }^{7}$ Law on Establishment of the State Commission for Decision Making in Second Instance Inspection Oversight and Misdemeanors (Official Gazette of RM no. 130/2014, 53/2016 and 11/2018). Decisions of the Constitutional Court of RM: U. br. 127/2014, September 30 ${ }^{\text {th, }}$ 2015, published in "Official Gazette of RM no. 183/2015 and U. br. 63/2017 ca 20. June 20 th, 2018, published in "Official Gazette of RM no. 122/2018.

${ }^{8}$ Art. 9, point. 6 and point. 7 and Art. 11, Law on Establishment of the State Commission for Decision Making in Second Instance Inspection Oversight and Misdemeanors.
} 
Table 3: State Commission for Decision Making in Second Instance Inspection Oversight and Misdemeanor

\begin{tabular}{l|cc} 
& 2016 & 2017 \\
\hline Members of the Commission & 7 & 7 \\
\hline Administrative Servants & 27 & 31 \\
\hline Cases from Previous year & 349 & 901 \\
\hline Newly formed cases & 3589 & 3170 \\
\hline Total workload (total cases being processed) & 3938 & 4071 \\
Solved & 3037 & 2903 \\
Unsolved & 901 & 1092 \\
\hline Disposition time & 108.29 & 137.30 \\
Clearance rate & 0.85 & 0.92 \\
\hline Back log. Rate of unsolved cases per 100 out of the total population & 0.04 & 0.05
\end{tabular}

\section{Administrative Court and Higher Administrative Court}

Formally the right to administrative dispute was introduced in Macedonian law during the early 1970s under the Supreme Court's jurisdiction however specialized judiciary was introduced in North Macedonia by a constitutional amendment (XXV) in 2005, providing that judicial power in the country be exercised by courts that are independent and autonomous. ${ }^{9}$ The constitution [base text] did not however prescribe the variety of courts, their types, and scope of competence, internal organization and procedures for operation. These issues were left to be determined by an organic law. Constitutional guarantees for legal protection were further operationalized by the Law on General Administrative Procedure, several sectoral Laws and Law on Administrative Disputes (Davkova and Deskoska 2017, 220).

The latter prescribes that administrative disputes be resolved before the Administrative Court, the Higher Administrative Court and the Supreme Court of [North] Macedonia. ${ }^{10}$ The Administrative Court is a court of first instance, deciding on lawsuits against final (non-conclusive) administrative decisions by state funds, public enterprises, public institutions, organizations and communities with public competencies that sign administrative contracts, decisions by municipal mayors when deciding on administrative matters and signs administrative contracts.

\footnotetext{
${ }^{9}$ The country carried the name North Macedonia from February 2019. From 1991 to 2019 the country bore the name Former Yugoslav Republic of Macedonia internationally, and internally it was called just Republic of Macedonia. Before 1991, the countries name was Socialist Federal Republic of Macedonia as a member republic of the Yugoslav federation, and for a brief period in after world war two it was self-declared the Peoples Republic of Macedonia.

${ }^{10}$ Law on Administrative Disputes (Official Gazette of RM no. 62/2006 and 150/2010).
} 
Table 4: Administrative Court

\begin{tabular}{|l|c|c|c|c|c|c|c|c|c|c|}
\hline & 2008 & 2009 & 2010 & 2011 & 2012 & 2013 & 2014 & 2015 & 2016 & 2017 \\
\hline Judges & 22 & 25 & 25 & 30 & 30 & 32 & 29 & 29 & 29 & 29 \\
\hline Court Servants & 33 & 50 & 47 & 44 & 45 & 55 & 58 & 58 & 58 & 58 \\
\hline Cases from Previous year & 5804 & 9154 & 10340 & 13866 & 15980 & 14228 & 12461 & 9786 & 9090 & 9156 \\
\hline Newly formed cases & 8497 & 9043 & 9792 & 11768 & 14675 & 1275413585 & 15011 & 13240 & 11306 \\
\hline Total workload (total cases being processed) & 1430118197 & 20132 & 25726 & 305912690726138 & 256812297820462 \\
\hline Solved & 5147 & 7857 & 6322 & 9746 & 1636314544153951589513888 & 12858 \\
\hline Unsolved & 9154 & 10340 & 13810 & 15980 & 14228 & 12461 & 1074310734 & 9786 & 7604 \\
\hline Disposition time & 649.2 & 480.3 & 797.3 & 598.5 & 317.4 & 312.7 & 254.7 & 246.5 & 257.2 & 215.9 \\
\hline Clearance rate & 0.61 & 0.87 & 0.65 & 0.83 & 1.12 & 1.14 & 1.13 & 1.06 & 1.05 & 1.14 \\
\hline $\begin{array}{l}\text { Back log. Rate of unsolved cases per 100 out of } \\
\text { the total population }\end{array}$ & & & & & & & & & & \\
\hline
\end{tabular}

The Higher Administrative Court is a second instance or appellative court, deciding upon appeals against verdicts made by the Administrative court in first instance. The Supreme Court has a special competence only for extraordinary legal instruments, against verdicts of the Higher Administrative Court.11

The number of judges in the administrative courts is determined by Judicial Council of North Macedonia. In first instance, administrative disputes are carried out by an individual judge or judicial council of three judges. Ordinarily, most cases are adjudicated in council. An individual judge resides over misdemeanor cases, which are sanctioned by fines lower than 5.00 euro, as well as misdemeanors for which do not include confiscation of items, prohibition of professional conduct and ban of working permission.

The Higher Administrative Court resides in judicial councils of three judges. ${ }^{12}$ Both courts are issued monthly quotas as minimal required number of resolved cases per judge for one month, by the Judicial Council. Between 2008 and 2016 the monthly quota for a judge in the Administrative Court ranged from 30 to 43 cases, while the quota for judges in the Higher Administrative Court varied around 22 cases per month (Gocevski 2017, 45).

Table 5. Higher Administrative Court

\footnotetext{
${ }^{11}$ Art. 16 and Art. 17.

${ }^{12}$ Art. 18, 18-a, 188-6, 18-B, 18-г.
} 


\begin{tabular}{|c|c|c|c|c|c|c|}
\hline & \multicolumn{6}{|c|}{2011201220132014201520162017} \\
\hline Judges & $14 \quad 12$ & 11 & 11 & 11 & 13 & \\
\hline Court Servants & 10 & 13 & 14 & 13 & 13 & 13 \\
\hline Cases from Previous year & 5 & 40 & 87 & 821 & 1095 & 990 \\
\hline Newly formed cases & \multicolumn{6}{|c|}{55175019823948434943885452} \\
\hline Total workload (total cases being processed) & \multicolumn{6}{|c|}{55175520224035443154836442} \\
\hline Solved & \multicolumn{6}{|c|}{50171519353953333644925692} \\
\hline Unsolved & 540 & 87 & 82 & 82 & 990 & 750 \\
\hline Disposition time & 36.58 .5 & 16.4 & 7.6 & 9.08 & 80.4 & \\
\hline Clearance rate & 0.910 .98 & 0.98 & $1.00 \mathrm{c}$ & 0.77 & 1.02 & 1.04 \\
\hline Back log. Rate of unsolved cases per 100 out of the total popu & 0.000 .00 & 0.00 & 0.000 & 0.00 & & \\
\hline
\end{tabular}

\section{METHODOLOGY}

This research was performed using a mixed method approach, by accessing to and processing quantitative and qualitative data sources (Barakso, Sabet and Schaffner 2014, 87, $88,190,110,112)$. The obtained quantitative data was recorded as interval data consisting of both integers and floating points (continuous data) expressed as: number of employees, number of cases and derived efficiency rates. The qualitative data was obtained from: statements recorded during interviews, analyzing documented data by the observed institutions (InDesk).

A unit of observation in the research was the performance of each institution in one year (country-year observation), with the available staff and workload during that year, effectively representing a cross-sectional analysis for several years. All institutions were observed for the entirety of their existence since they were established/began operation until the end of 2018. All units of observation were monitored for the same parameters, throughout time thus combining longitudinal data with cross-sectional data into a time series data i.e. also known as a panel study.

The effect of intervening variables, on the amount of influence employees have on institutional performance indicators was tested by grouping the observed institutions by status (courts and state commissions, as each is governed by a different legal regime while both in essence oversee the legality of administrative decisions), and looking for statistically significant differences in the performance indicators of the two groups.

Techniques used for quantitative data processing are fixed-effect panel data estimation (or multivariate linear 'panel' regression) and a means comparison using an independent sample t-test (Moore 2000, 390, 401, 406). 


\section{RESULTS FROM STATISTICAL ANALYSIS}

\section{Fixed Effects Panel Estimation Results}

Units of analysis are the five institutions. Rather than to look at differences between the 5 institutions at a particular year, the fixed-effects panel data estimation looks at differences within these institutions over time. This way we also attempt to avoid risk of reverse causality in our inferences (Barakso, Sabet and Schaffner 2014, 171-172; Moore 2000). The number of observations may seem small for a panel regression analysis, however in this particular study they represent the entire population for a time series, encompassing both longitudinal and cross-sectional data, and not a sample size. Both panel results were tested for robustness to ensure consistent results in the inferred relationship between the independent variables (x1-decisionmakers and $\mathrm{x} 2$-servants) and the tested dependent variable (Y1-clearance rate) regardless of other factors or specifics of the model.

A static panel fixed effect model of the clearance rate - presented in Table 6 demonstrates that staff, both decision makers $(x 1, \beta=0.034, p=0.012)$ and servants $(x 2$ $\beta=0.007, p=0.002)$ in all five institutions are significant predictors of clearance rates (Y1) and the regression coefficient explain $65 \%\left(R^{2}=0.65\right)$ of the variance in clearance rates. The remaining $35 \%$ of the variance we deduce can be explained by other factors, not directly observable from our study, but confirmed by data obtained via interviews and at premise survey of premises.

\section{Table 6: Fixed Effect Clearance Rate x1 x2}

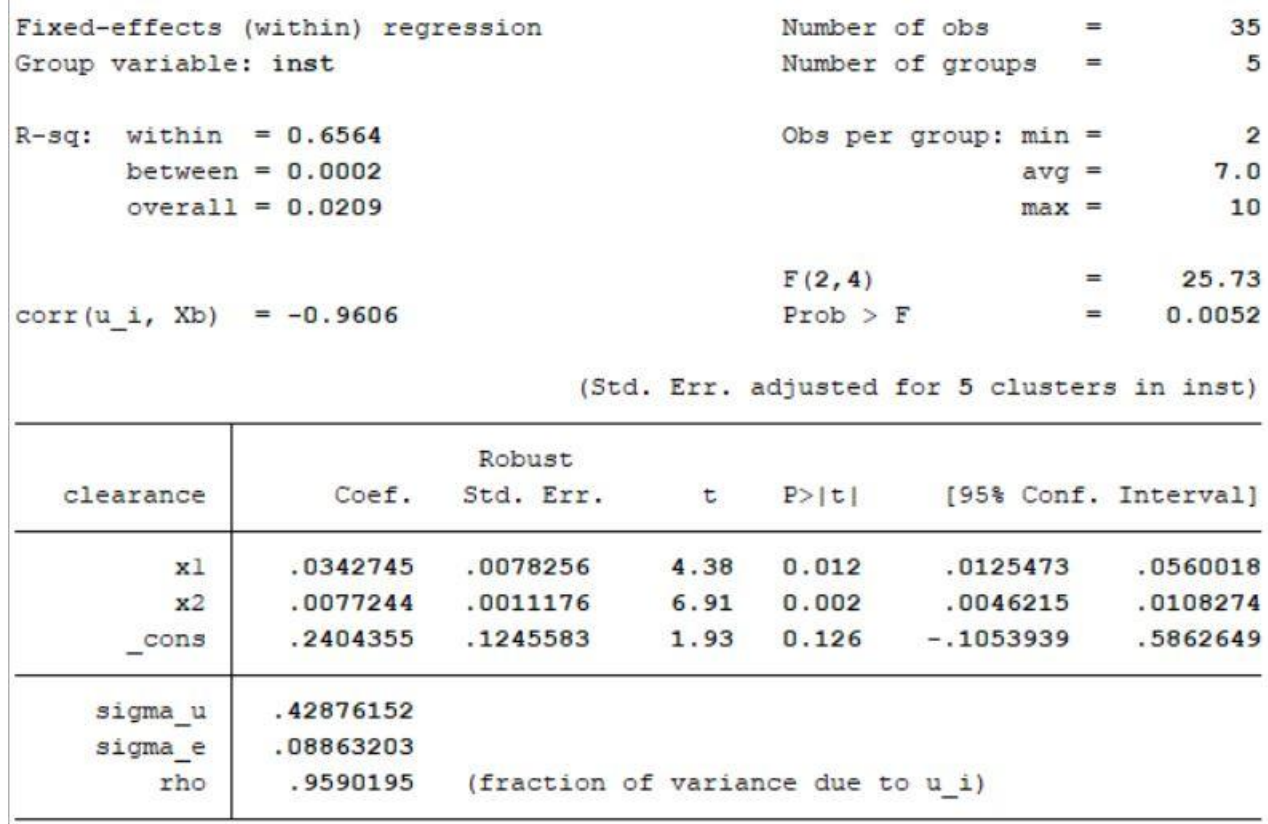


We also use a dynamic panel data approach, which considers the influence of previous years to the performance and behavior of organizations. As presented in Table 7, the coefficient on the staff has higher statistical significance that decision makers $(x 1 \beta=0.4$, $\mathrm{p}=0.002)$ and servants $(x 2 \beta=0.009, p=0.001)$ are predictors of clearance rates $(Y 1)$. The independent variables in the model explain $72.5 \%\left(R^{2}=0.725\right)$ of variance in clearance rates, leaving less than 30\% of the variance to be explained by other factors. We assume the remaining variance can be explained by the factors expressed by judges, commission members and administrative servants during interviews such as working conditions, the quality of intra-institutional communications, do institutions deliver cases between themselves quickly and without errors in documentation, ICT and other equipment at their disposal but we cannot test the individual effect of each aforementioned factor, hence they cumulative represent a deduced value as an intervening variable.

\section{Table 7: Fixed Effect Clearance to X1 X2 Clearance Lagged From Previous}

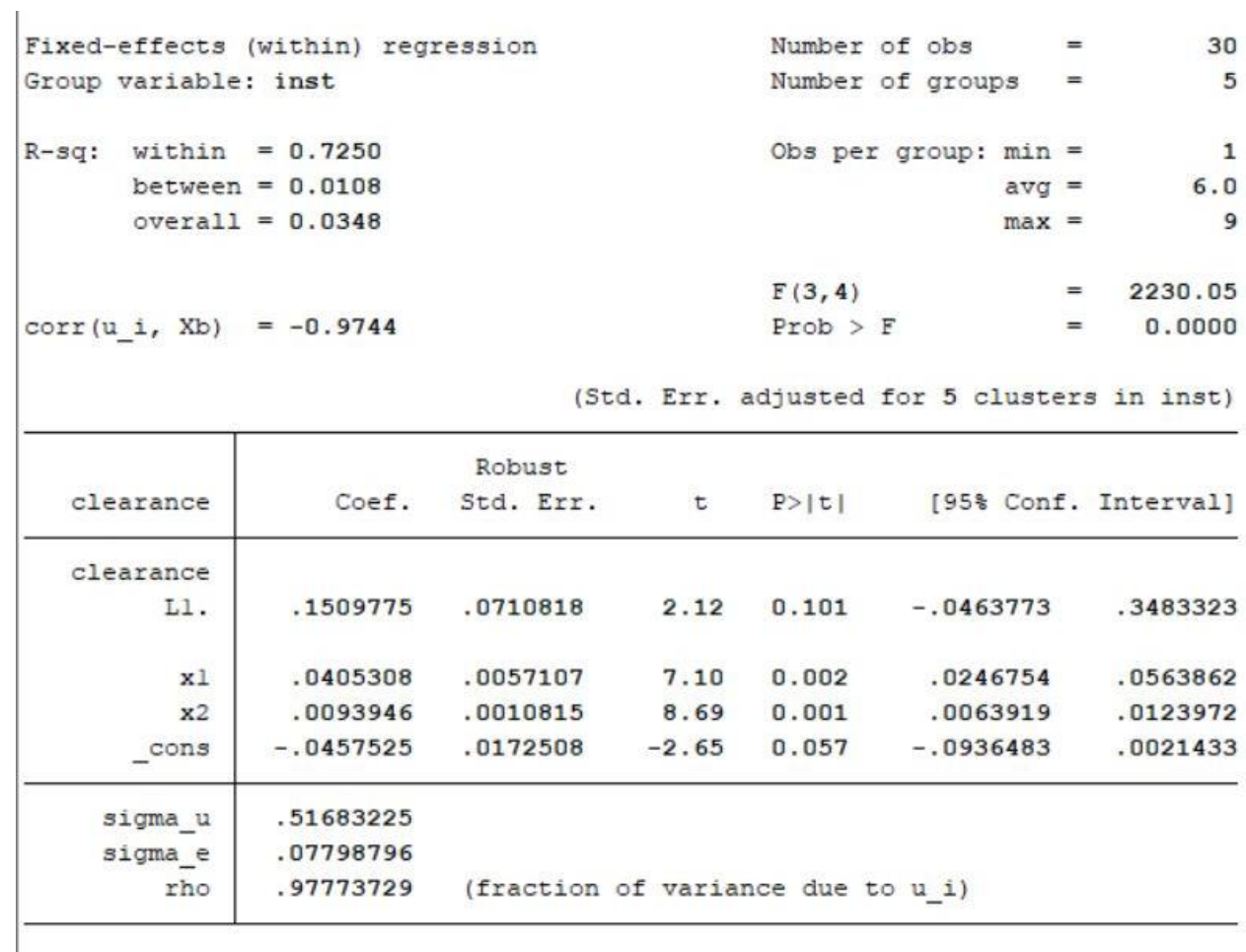

What this means is that more staff will affect positively performance indicators but not by much, and not on long term. Other measures should be taken to improve intra institutional and inter-institutional communication. When interpreting these results, one must consider inherent risks every causal inference confronts in a large $N$ study using crosssectional data. We acknowledge two sources of potential endogeneity: possible reverse causality and omitted variable bias (Stojkov 2009, 72-75). 
This study attempts to address the problem of the omitted variable bias by including as many possible external factors which may affect productivity, expressed as meaningful by judges, commission members and administrative servants employed in each of the observed institutions in the sample. We also try to avoid stepping into the reversed causal inference trap (as a separate source of endogeneity) by carefully formulating a hypothesis which explains whether the number of employees affects productiveness expressed by Y1-clearance rate, and how much of the variance in clearance rates are explained by the independent variables. Both diagrams show that $x 1$ and $x 2$ do explain a large share of clearance rates - we attribute the remaining share of variance in $\mathrm{Y} 1$ to other factors. We also do not reject a possible and very probable explanation that faced with increasing workloads resulting with a decrease of productivity indicators institutions did in fact increase the number of staff thus acting reactively. But we do strongly support the claim that productivity is not necessarily increased only by employing new staff- but rather a meaningful degree of productivity can be achieved by improving working conditions, inter-institutional communication, digitalization of document management within and between institutions etc. We also support the claim that institutions adapt to their workload over time.

In times of excess workloads they can increase working hours, or monthly quotas, while in periods of decreased workloads the decrease the amount of cases per available decision maker/team of civil servants or for judges they lower monthly quotas - thus they may exhibit similar clearance rates regardless of actual workload, even though they are spending more on salaries and (cumulatively) doing less. It is only in significant drops in clearance rates and increase in backlogs that one may support additional staffing.

\section{Means Comparison between State Commissions and Administrative Courts Performance Indicators (independent sample t-tests)}

Comparing mean values for select performance indicators for statistically significant differences $\left({ }^{*} p<.05,{ }^{*} p<.01\right)^{13}$ between courts and state bodies that provide legal protection in administrative procedures in North Macedonia, we obtained results for six parameters in the observed institutions (Table 8).

Table 8: Means Comparison of Performance Indicators

\begin{tabular}{lll}
\hline & Courts & Commissions \\
Clearance Rate & 0.96 & 0.92 \\
Workload per decision maker & 597.86 & 411.45 \\
Disposition time & $254.62^{\star *}$ & $65.37^{\star *}$ \\
Average solved cases in one year & $8187.53^{\star *}$ & $2301.56^{\star *}$ \\
Number of servants per decision maker & $1.49^{* *}$ & $2,94^{\star *}$ \\
Workload per servant & $380.08^{\star *}$ & $135.42^{\star *}$
\end{tabular}

${ }^{13}$ If there is no star, differences are not considered statistically significant. 
Journal of Liberty and International Affairs | Vol. 6, No. 2, 2020 | elSSN 1857-9760

Published online by the Institute for Research and European Studies at www.e-jlia.com

Table 9:

\begin{tabular}{lll}
\hline & Courts & Commissions \\
\hline Mean & 0.96 & 0.92 \\
Variance & 0.03 & 0.02 \\
Observations & 17.00 & 18.00 \\
Hypothesized Mean Difference & 0.00 & \\
df & 31.00 & \\
t Stat & 0.72 & \\
$P(T<=t)$ one-tail & 0.24 & \\
t Critical one-tail & 1.70 & \\
$P(T<=t)$ two-tail & 0.48 & \\
$\mathrm{t}$ Critical two-tail & 2.04 & \\
\hline
\end{tabular}

Clearance Rate
Disposition Time

Table 10:

\begin{tabular}{lll}
\hline & Courts & Commissions \\
\hline Mean & 254.62 & 64.37 \\
Variance & 61958.97 & 6524.16 \\
Observations & 17.00 & 18.00 \\
Hypothesized Mean Difference & 0.00 & \\
df & 19.00 & \\
t Stat & 3.01 & \\
$P(T<=t)$ one-tail & 0.00 & \\
t Critical one-tail & 1.73 & \\
$P(T<=t)$ two-tail & 0.01 & \\
t Critical two-tail & 2.09 & \\
\hline
\end{tabular}

Table 11:

Workload per decision maker

\begin{tabular}{lll}
\hline & Judges & Members of Commissions \\
\hline Mean & 597.86 & 411.45 \\
Variance & 89487.88 & 169514.20 \\
Observations & 17.00 & 18.00 \\
Hypothesized Mean Difference & 0.00 & \\
df & 31.00 & \\
t Stat & 1.54 & \\
$P(T<=t)$ one-tail & 0.07 & \\
t Critical one-tail & 1.70 & \\
$P(T<=t)$ two-tail & 0.13 & \\
t Critical two-tail & 2.04 & \\
\hline
\end{tabular}


Table 12:

\begin{tabular}{lll}
\hline & Judges & Commissions \\
\hline Mean & 8187.53 & 2301.56 \\
Variance & 31045491.26 & 5009412.50 \\
Observations & 17.00 & 18.00 \\
Hypothesized Mean Difference & 0.00 & \\
df & 21.00 & \\
t Stat & 4.06 & \\
$P(T<=t)$ one-tail & 0.00 & \\
t Critical one-tail & 1.72 & \\
$P(T<=t)$ two-tail & 0.00 & \\
t Critical two-tail & 2.08 & \\
\hline
\end{tabular}

\begin{tabular}{lll} 
Table 13: & maker & \\
\hline & Courts & Commissions \\
\hline Mean & 1.49 & 2.94 \\
Variance & 0.20 & 2.14 \\
Observations & 17.00 & 18.00 \\
Hypothesized Mean Difference & 0.00 & \\
df & 20.00 \\
t Stat & -4.01 & \\
$P(T<=t)$ one-tail & 0.00 & \\
t Critical one-tail & 1.72 & \\
$P(T<=t)$ two-tail & 0.00 & \\
$t$ Critical two-tail & 2.09 & \\
\hline
\end{tabular}

Clearly courts have a larger volume of work compared to any one commission. This is a systemic consequence and has little to do with the commissions themselves. There is only one first instance administrative court and one second instance administrative court competent to reside over all administrative disputes. The Higher Administrative Court resides over all appeals against the first instance court verdicts. Second instance decision making i.e. appellative protection in administrative procedures is functionally decentralized between three state bodies (the observed commissions) and two ministerial commissions (not observed in this study) so it's no wonder said bodies have a smaller volume of work individually. However, the visible differences in volume of work do not significantly affect productiveness, which is deduced from the fact that there is no significant difference in the clearance rates between the two groups of institutions. 
A proposed explanation for this is that all institutions after a period adapt to their workload and working conditions (in North Macedonia) to achieve a satisfactory [after a while similar between observed institutions] level of efficiency.

An expected discrepancy between disposition times is also evident for the two groups. Understandably, state bodies are subject to prescribed deadlines and they apparently do as the mean value for their dispositions close to the longest prescribed deadline of 60 days, because this deadline applies to a largest number of cases. Administrative courts resolve a case between 8 and 9 months. The volume of work per judge however is not significantly different from the number of cases per member of commission. The mean values for workloads per decision maker are visibly different between the two groups, however due to their large internal variance (the difference from the smallest workload per judge and the smallest workload per member of commission is too wide from their largest values) we derive that this mean number is circumstantial in both cases - a result obtained by chance, which may significantly change if the circumstances change even slightly.

It is evident that judges in administrative courts have fewer administrative servants at their disposal to aid in processing cases, a circumstance we consider meaningful because it inhibits judicial productivity, and thus we predict that an increase in administrative staff directly assisting case processing will positively affect productivity more significantly than an increase in the number of judges.

Although administrative servants in commissions are encumbered by a lower workload per servant than court servants, we still deduce a similar conclusion. A higher number of administrative servants involved in case processing will affect the commissions productivity better (if internally allocated rationally) than an increase if the number of commission members. However, the impact increasing administrative staff in commission we expect to be smaller than an increase of court servants will have for judicial performance.

\section{CONCLUSION}

The preferred mechanism to tackle increasing workloads in the observed institutions obviously was increasing staff. As more cases were formed and/or residual cases from previous years accumulated, commissions and administrative courts hired more people (respectively). Having and understanding of the dynamics of administrative legal protection, we posit ourselves that institutions do not have an influence to the amount of newly formed cases per year as they cannot predict how many dissatisfied parties will object to administrative decisions. Nor can the courts precisely anticipate how many lawsuits will be made against the second instance decisions made by the commissions covered by this study. They can only influence their internal processes and to a limited degree the communication they have with other institutions. Thus, they can only find ways to adapt to a rise or drop in workloads, which since 2008 appears to be mostly by employment - and to a lesser degree 
(but difficult to measure accurately) to internal optimizations. We thus infer that the institutions covered by this study employ as a reaction not as anticipatory action.

Employees (decision makers and staff) explain up to $72.5 \%$ of the variance in productivity in the observed population. Employing new staff will not necessarily improve productiveness; on the contrary it might bring it down and rise operating costs. Workload per administrative servant is not proportional to the workload per decision maker. The same disproportion applies to internal allocation of labor in the observed commissions. A single case typically moves through two or more tiers of control meaning that it is processed in varies levels by two or more servants, in other words to ensure quality they allocate more manpower to (re)do the same cases, before finally it is adopted by the commission members.

Administrative courts also show the tendency to increase the number of judges with rising workloads. However, a rise in the number of staff does not appear to significantly follow an increase in clearance rates. Disposition times and backlog show a tendency to increase as number of staff increases.

Complementing these tendencies to panel results we infer that when faced with higher workloads, courts hired more judges and servants until productiveness appeared to increase to meet the challenge.

All observed institutions exhibited reactive behavior when faced with increasing workloads rather than programmatic and anticipatory.

Administrative courts undisputedly have larger volumes of work than each commission, which is explained by their position and role in the states administrative system. Substantially, administrative courts are competent to provide legal protection for [virtually] all administrative cases, will commissions are functionally decentralized thus are competent provide legal protection in fewer sectors of administrative affairs. Even the commission deciding in second instance administrative procedure, with the broadest specter of competence deriving from over 150 laws still averages to half the workload of the Administrative Court (in first instance), though we must accept that in 2017 the commission also had half the staff compared to the court. Pressure affecting the working process in commissions comes from prescribed deadlines, thus even though faced with lower workloads commission employees are forced to resolve them in determined and significantly shorter time frames (15 to 60 days). Administrative judges on other hand are pressed to meet a monthly quota. Research however showed that regardless organizational format, internal or external factors, after some time (3-4 years) institutions balance out inputs and outputs achieving (with more or less success) efficiency. This is seen in positive productivity indicators which rise following the first few years of the institutions' establishment, and there is no significant difference in the performance indicators between courts and commissions. If we were to comment contemporary staffing conditions, tendencies could justify employing more administrative servants in the administrative court of first instance, however until a 1:1 ratio between judges and servants directly involved in case proceedings i.e. 28 judges and 28 servants, and only then allocating remaining administrative staff to other critical positions we 
predict administrative judges will rely more on personal capacities rather than on support by their administration to resolve cases. Thus it is difficult to with certainty predict the effect one more administrative servant may have on court productivity.

Improving external factors which explain almost $30 \%$ of the variance in clearance rates remain a general recommendation because they are to a large degree beyond the scope of influence by the institutions themselves. Such recommendations include fewer and less frequent changes to the legal framework, improving inter-institutional communication channels thus speeding up response times between them, digitizing document management etc. Possibly, one may recommend physically locating all five institutions within one building sharing a single archive.

In summary, we infer the independent variables affect productivity in the observed institutions regardless of their organizational format and specific legal regime. We cannot support that external factors affect commission productivity differently than they affect courts.

Evident differences in operational practices and volume of work are nominal only, resulting from circumstance and are not related to the type of organization. Undisputedly, the number of employees affects productivity but is not the only affecting factor. Internal allocation of labor, internal procedures, quality of internal communication channels [proper management] as well as inter-institutional communications contributes to about a third of the productivity.

We firmly claim that the arguments support the working hypothesis (the null hypothesis is unsupported) and adequate allocation of labor and workloads resulting in a degree of productivity of one institution, also affects overall systemic efficiency in the provision of legal protection in administrative affairs in North Macedonia. Argument also support the assumption, that properly developed inter-institutional channels expedite exchange of documents and their quality, thus minimizing data loss, chance of errors and speeds up overall proceedings, hence enabling courts and commissions to execute their tasks in case resolution quicker and with more accuracy. 
Journal of Liberty and International Affairs | Vol. 6, No. 2, 2020 | elSSN 1857-9760

Published online by the Institute for Research and European Studies at www.e-jlia.com

\section{ACKNOWLEDGMENTS}

This paper was previously presented at the 27th NISPAcee Annual Conference, organized under the auspices of the Faculty of science, Charles University in Prague (Czech Republic), 24-26 May 2019. 


\section{REFERENCES}

1. Adalmir, Gomes O., Guaimaraes A. Tomas, Akutsu Luis. 2016. "Relationship between Judicial Staff and Court Performance (Brazil), International Journal of Court Administration, Vol 8, No 1: 12-19, DOl:10.18352/ijca.214

2. Annual Report on the Work of the State Commission for Appeals in Public Procurements, 2016.

3. Annual Report on the Work of the State Commission for Appeals in Public Procurements, 2017.

4. Annual Report on the Work of the State Commission for Decision Making in Second Instance in Administrative Procedure and Labor Disputes, 2017, available at: http://www.dkz.mk/sites/default/files/dokumenti/Godisen\%20izvestaj\%202017.pdf

5. Annual Report on the Work of the State Commission for Decision Making in Second Instance in Inspection Oversight and Misdemeanors, 2017.

6. Annual Report on the Work ofthe Administrative Court Skopje, 2017, available at: www.sud.mk

7. Akimovska Maletic, Iskra and Predrag Dimitrijevic. 2015. Administrative Law, St. Kliment Ohridski University - Bitola, Faculty for Security - Skopje.

8. Barakso, Maryann, Daniel M Sabet and Brian Schaffner. 2016. Understanding Political Science Research Methods the Challenge of Inference, Routledge Taylor and Francis, New York and London.

9. Colin, Lindsay and Roland McQuaid. 2008. InterAgency Cooperation - Experiences in three vanguard Active Welfare States.Social Policy and Society.

10. Dimitrijevic, Predrag. 2017. Administrative Law, General Part. Fourth Edition, Nis.

11. Decision by the Constitutional Court of the Republic of Macedonia: U. br. 127/2014 from September 30, 2015. Published in "Official Gazette of the Republic of Macedonia" No. 183/2015.Decision by the Constitutional Court of the Republic of Macedonia: $U$. br. 63/2017 from June 20, 2018. Published in "Official Gazette of the Republic of Macedonia" No.122/2018.

12. Gocevski, Dragan. 2017. Administrative Legal Protection of Citizens and Employees in Public Administration, Report on the Operation of Second Instance Commissions and Administrative Courts, Center for Change Management,published in the frame of the project "Monitoring Administrative Justice", supported by the UK Government, Skopje, available at: http://www.cup.org.mk/publications/Zastita-nagragjanite_MAK_za\%20pechat.pdf

13. Koprić, Ivan. 2011. "Europski upravniprostor - različiti pristupi, slični ishodi", Paper Almanach of the lustinianus Primus Faculty of Law Skopje, Published Proceedings from the International Scientific Conference "Developing Trends in Administrative Legislation" 24-26 June 2017, Skopje. 6-37. 
14. Law on Public Procurements ("Official Gazette of the Republic of Macedonia "No.136/2007, 130/2008, 97/2010, 53/2011, 185/2011).

15. Law on Establishing the State Commission for Decision Making in Administrative Procedure and Labor Disputes in Second Instance ("Official Gazette of the Republic of Macedonia" No. 51/11, 148/13 и 41/14, 130/14, 53/2016 and 11/2018).

16. Law on Establishing the State Commission for Second Instance Decision Making in Inspection Oversight and Misdemeanor Procedure ("Official Gazette of the Republic of Macedonia" No. 130/2014, 53/2016 и 11/2018).

17. Law on Administrative Disputes ("Official Gazette of the Republic of Macedonia" No. 62/2006 и 150/2010).

18. Moore S., David. 2000. The Basic Practice of Statistics $2^{\text {nd }}$ Ed., W. H. Freeman and Company.

19. Nashold, Frieder, and Casten von Otter. 1996. Public Sector transformation, Rethinking Markets and Hierarchies in Government.Dialogues on Work and Innovation. ed. Hans Van Beinum, Center for Working Life Research and Development, Halmstad University, John Benjamins Publishing Company.

20. OECD, Defining and Measuring Productivity, available at: https://www.oecd.org/sdd/productivity-stats/40526851.pdf

21. Quist, Martin. 2016."Activation Reform and InterAgency Cooperation, Social Policy and Administration, Vol 50, No 1:19-38, DOI: 10.1111/spol.12124

22. Quarterly data on the work of courts, Judicial Council of Republic of [North] Macedonia, 2017, available at: www.sud.mk

23. Stojkov, Aleksandar. 2009. Current Account Deficits and Economic Growth, Evidence from the South Eastern European Economics, Skopje: Iustinianus Primus Faculty of Law Skopje.

24. Siljanovska - Davkova, Gordana and Renata Treneska - Deskoska.2017. "Dilemmas and challenges of legal protection against administrative actions in the Republic of Macedonia" in: The principle of effective legal protection in administrative law: a European comparison. Edited by Zoltan Szente, Konrad Lachmayer, 218-230. London and New York: Routledge, available at: https://books.google $\cdot \mathrm{mk} / \mathrm{books}$ ? id=2cvLDAAAQBAJ\&pg=PA218\&lpg=PA218\&dq=ad ministrative + protection + macedonia\&source=bl\&ots $=S X Y 0$ gqTMGJ\&sig $=$ Rcmlf4RxofA IEAhRRdozn1a6UJs\&hl=en\&sa=X\&ved=2ahUKEwiq47zP8IDfAhVvAxAlHcY7Bvs4ChDo ATAGegQICBAB\# $\mathrm{v}=$ onepage $\& \mathrm{q}=$ administrative\%20protection\%20 macedonia\&f=false

25. The 2018 EU Justice Scoreboard, European Commission, 2018 Luxembourg, available at: https://ec.europa.eu/info/sites/info/files/justice scoreboard 2018 en.pdf 